\title{
Respiratory Tract Disorders Associated with Changes of the Mucous Membrane in Workers often Exposed to Pathological and Toxic Factors
}

\author{
Elida Tairovna Topchubaeva*, Zhazgul Bukarbaevna Imetova, Akshoola Kozmanbetovna \\ Turusbekova, Baktyar Omurbekovich Abdurahmanov, Roman Kalmatovich Kalmatov
}

Osh State University, Osh, Kyrgyzstan

Received: 01/06/2020

Accepted: 08/10/2020

Published: 20/12/2020

\begin{abstract}
This article is investigating changes in the mucous membrane of the respiratory tract in workers who are often exposed to pathological and toxic factors. Research methods and materials: Air sampling was performed by aspirator and gas analyzer. Collected air was checked for chemical composition. Results and discussions: Air sampling of the working area detected toxic substances such as dust, soot and toxic gases: $\mathrm{SO}_{2}, \mathrm{~N}_{2} \mathrm{O}_{5}, \mathrm{~N}_{2} \mathrm{O}_{4}, \mathrm{NO}_{2}, \mathrm{~N}_{2} \mathrm{O}, \mathrm{CO}$ and $\mathrm{H}_{2} \mathrm{~S}$. Concentrations of these toxic substance and gases varied from $0.06-15.8 \mathrm{mg} / \mathrm{m}^{3}$. Mechanisms of toxic effects causing occupational disorders by various substances and chemicals described. Conclusions: Respiratory tract disorders including chronic bronchitis, allergic bronchitis, chronic obstructive pulmonary disease and lung cancer in workers exposed to pathological and toxic factors have been described.
\end{abstract}

Keywords: Respiratory tract disorders, mucous membrane, workers, substances and gases, air sampling

\section{Introduction}

At the present time an adverse effect of toxic environmental factors on the human immune system was generally recognized [1-3]. The influence of such factors on the biological property of microbiota bacteria, which is a fundamental component of the macroorganism protection system, has been reported [4]. Lungs exposure to the toxic substances from different sources in the environment may lead to acute [5] and chronic pulmonary [6] or even systemic inflammation disorders [7]. Mechanism of toxic action exerted by the irritant gases may cause widespread and severe injury of the epithelial lining of the bronchioles which leads to acute respiratory symptoms including lung edema [8]. Types of toxic substances which are participating in the toxicity mechanism are: irritants, sensitizers, genotoxicity, carcinogens, mutagens, teratogens and reproductive toxins [9] as shown in the Figure 1. Normal function of the respiratory tract mucous membrane and its immunological response should be considered depending on the inhaled air components, pollutants, or allergens [10]. Dehydration of the respiratory mucous membrane causes an increase in viscosity of the mucosal fluid and, hence the ciliary clearance becomes less effective [11]. Mucociliary clearance has important function in innate defense mechanism against inhaled microbes and irritants and can be affected by exogenous factors such as smoke, dust and infections [12]. Inhaled toxins are trapped in the airway mucus and transport them from lungs in the forms of ciliary interactions and cough by making lungs vulnerable to injury [13].

It is known that workers of various factories are exposed to a wide range of toxic substances that potentially have a negative effect on their health. However, data on the characteristics of the state of the mucous membranes of the UDT and the relationship with the immune status of the body in representatives of these contingents are practically absent in the available literature. In this article we are describing working air composition obtained during air sampling from the Aravan cement factory.

\section{Research methods and materials}

Air sampling from the production area (sampling No. GOST12.1005-88) and conservation was collected by air filter AFA VP-20. Measurement tools for air sampling used: aspirator (Meteoscope M) and gas analyzer (Signal 4M). Survey method based on the medical checkup of respiratory organs was applied in the determination of people with respiratory disorders. Respiratory tract disorders were registered in the Aravan region, Osh (2014-2018 years). Conditions and time for an air sampling are shown in the Table 1.

Corresponding author: Elida Tairovna Topchubaeva, Osh State University, Osh, Kyrgyzstan. E-mail: topchubaeva@ oshsu.kg 


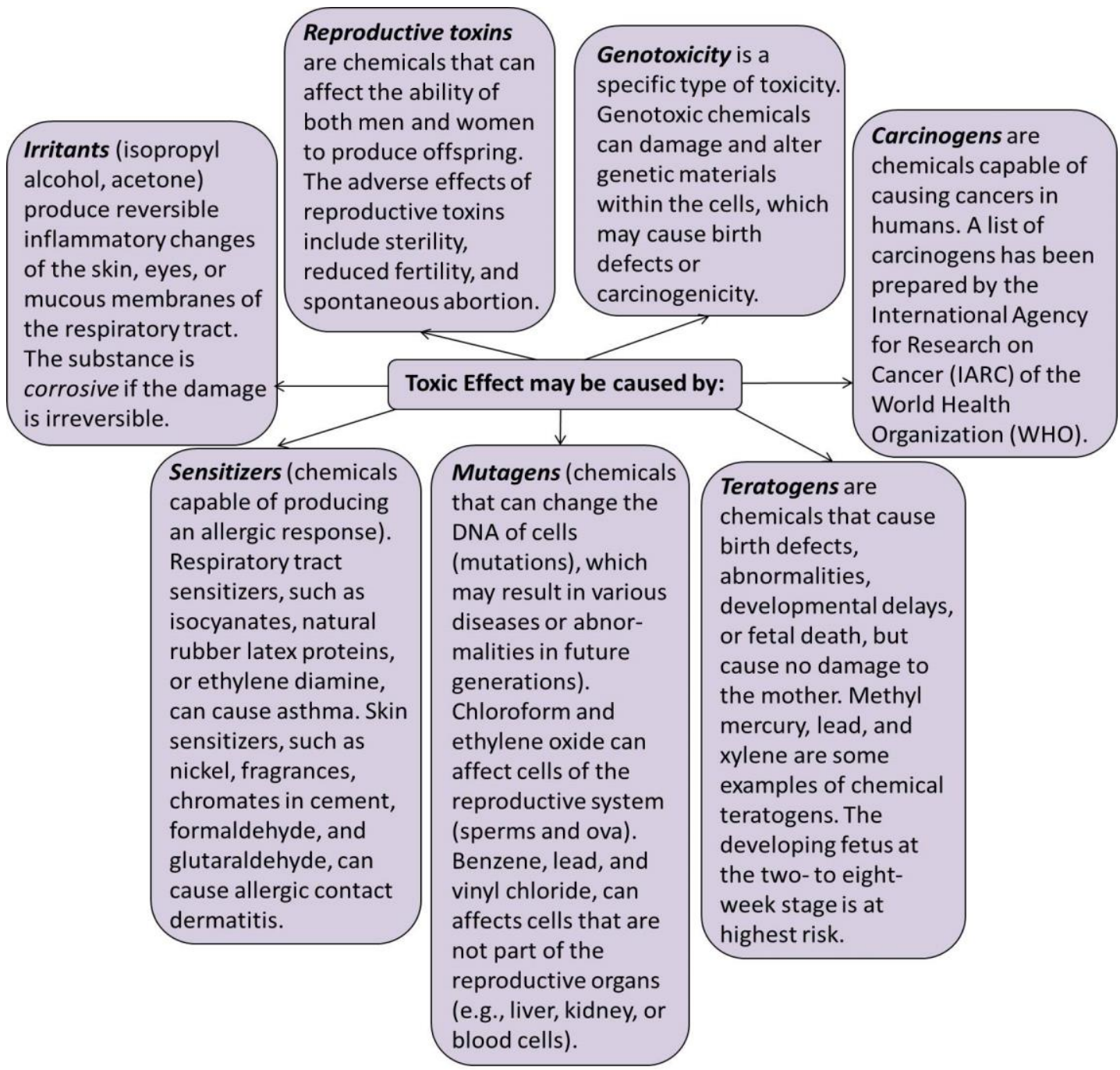

Figure 1: Figure 1. Mechanisms of toxic effects causing occupational disorders by various chemicals such as Metalliferous carcinogens (Ar, Be, Cd, Cr, Ni), Aromatic amine carcinogens (4-aminibiphenyl and its nitro derivatives, B-Naphthylamine), Ethylene oxide, Formaldehyde, Polycyclic aromatic hydrocarbons and aromatic amines (adapted from [9]).

Table 1: Conditions and time for air sampling used for determination air of the working environment

\begin{tabular}{|c|c|c|c|c|c|c|c|}
\hline \multirow[b]{2}{*}{$\stackrel{\circ}{Z}$} & \multirow[b]{2}{*}{ 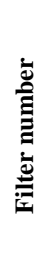 } & \multicolumn{3}{|c|}{ Air sampling conditions } & \multicolumn{3}{|c|}{ Time } \\
\hline & & 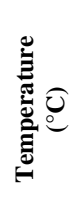 & 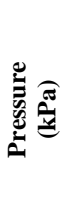 & 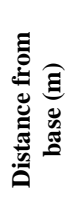 & 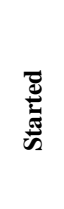 & 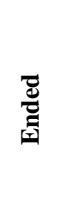 & 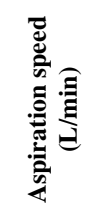 \\
\hline 1 & $1-3$ & 21.42 & 89 & 1.5 & $13^{10}$ & $13^{20}$ & 200.102 \\
\hline 2 & $3-6$ & 24.21 & 89 & 1.5 & $14^{50}$ & $15^{20}$ & 200.102 \\
\hline 3 & $6-9$ & 24.41 & 89 & 1.5 & $15^{25}$ & $15^{35}$ & 200.102 \\
\hline
\end{tabular}

\section{Results and discussions}

Air sampling conditions and determination time of the working environment of the Aravan cement factory are shown in the Table 1. Filters 1-3, 3-6 and 6-9 were used; temperature was $21.42-24.41^{\circ} \mathrm{C}$, pressure was $89 \mathrm{kPa}$, distance from the base 1.5 meters, aspiration speed of $200.102 \mathrm{~L} / \mathrm{min}$ was applied. Air sampling time was lasted for $10-30$ minutes. Concentrations, kinds of toxic substances and gases in air of the working environment were measured by the meteorological department in 28.06.2019, measurement certificate No. 16/1-4 (Table 2). The data obtained on the concentration of toxic components and gases in the inhaling air of workers showing their increased concentrations. Usually, air is containing the following substances: nitrogen $\left(\mathrm{N}_{2}\right)-78.084$ mole percent (m.p.), oxygen $\left(\mathrm{O}_{2}\right)-20.947$ m.p., argon (Ar) - 0.934 m.p., carbon dioxide $\left(\mathrm{CO}_{2}\right)$ - 0.0350 m.p., neon $(\mathrm{Ne})-0.001818$ m.p., helium $(\mathrm{He})-0.000524$ m.p., methane $\left(\mathrm{CH}_{4}\right)-0.00017$ m.p., krypton $(\mathrm{Kr})-0.000114$ m.p., hydrogen $\left(\mathrm{H}_{2}\right)$ - 0.000053 m.p., nitrous oxide $\left(\mathrm{N}_{2} \mathrm{O}\right)$ 0.000031 m.p., xenon $(\mathrm{Xe})-0.0000087$ m.p., ozone $\left(\mathrm{O}_{3}\right)-0.0008$ 
m.p., carbon monoxide (CO) - 0.000025 m.p., sulfur dioxide $\left(\mathrm{SO}_{2}\right)$ - 0.00001 m.p., nitrogen oxide $\left(\mathrm{NO}_{2}\right)-0.000002$ m.p., ammonia $\left(\mathrm{NH}_{3}\right)$ - 0.0000003 m.p. [14].

Table 2: Concentrations and kinds of toxic substances and gases in air of the working environment

\begin{tabular}{|l|l|l|l|}
\hline No. & Filter number & Air component & $\begin{array}{l}\text { Concentration } \\
\left(\mathrm{mg} / \mathrm{m}^{3}\right)\end{array}$ \\
\hline 1 & $1-3$ & Dust and soot & 15.8 \\
\hline 2 & $1-3$ & $\mathrm{SO}_{2}$ & 10 \\
\hline 3 & $1-3$ & $\mathrm{~N}_{2} \mathrm{O}_{5}, \mathrm{~N}_{2} \mathrm{O}_{4}, \mathrm{NO}_{2}, \mathrm{~N}_{2} \mathrm{O}$ & 0.27 \\
\hline 4 & $1-3$ & $\mathrm{CO}$ & 0.12 \\
\hline 5 & $1-3$ & $\mathrm{H}_{2} \mathrm{~S}$ & 10 \\
\hline 6 & $4-6$ & $\mathrm{Dust}$ and soot & 16 \\
\hline 7 & $4-6$ & $\mathrm{~N}_{2} \mathrm{O}_{5}, \mathrm{~N}_{2} \mathrm{O}_{4}, \mathrm{NO}_{2}, \mathrm{~N}_{2} \mathrm{O}$ & 0.61 \\
\hline 8 & $4-6$ & $\mathrm{CO}$ & 0.08 \\
\hline 9 & $4-6$ & $\mathrm{SO}_{2}$ & 22.5 \\
\hline 10 & $7-10$ & $\mathrm{Dust}$ and soot & 2.8 \\
\hline 11 & $7-10$ & $\mathrm{SO}_{2}$ & 0.06 \\
\hline
\end{tabular}

Qualitative and quantitative compositions of air were changed during the working procedure of factory machines. Despite the fact that the majority of substances with irritating effects were known, it is often impossible to establish reliably the cause of the pathological conditions of heavy industry workers. Inhaling air in the working area may consist of small size particles including various chemical compounds, in particular formaldehyde, alkanolamines, triazoles and volatile organic substances $[15,16]$. It has been established that $70 \%$ of plant workers suffer from skin and upper respiratory tract diseases [17]. The oil-dispersant mixtures in the working area cause respiratory symptoms, longlasting airway oxidative stress and systemic genetic disorders due to presence of mutagenic/carcinogenic chemicals including PAH, benzene, and benzene derivatives [18]. A high prevalence of symptoms (in particular, nasal congestion, runny nose and sore throat) has been shown to be characteristic of acute rhinosinusitis and allergic rhinitis [19]. Signs of mucosal irritation caused by the presence of toxic substances in the workplace have been studied.

\subsection{Disorders associated with changes in the mucous membrane of respiratory tract}

Mucous secretions have important function in protection of lungs against chronic lung disease [20]. Upper respiratory airway symptoms may occur due to exposure to irritants such as throat and nose irritation, nasal congestion, rhinorrhea, postnasal drip, nasal drying and sneezing [21]. Mucosal immunity represented in the Figure 2 is constituted by mucosa-associated lymphoid tissue and regional mucosa-draining lymph nodes (LNs), effector sites consisting of different histological parts including the lamina propria [22].

\subsection{Chronic bronchitis}

Chronic bronchitis (CB) defined as a condition of excess mucus secretion in the bronchial tree, occurring on most days for at least 3 months per year for at least 2 consecutive years [23]. In $\mathrm{CB}$ there is overproduction and hypersecretion of mucus by goblet cells, leading to airflow luminal obstruction of small airways, changes in the epithelium, and alteration of airway surface tension predisposing to collapse [24]. CB associated clinical features are lung function impairment, increasing risk of exacerbations [25]. Symptoms [26] such as dyspnea subjective sensation of shortness of breath and discomfort or an abnormal awareness of breathing [27], chronic cough which is defined as cough present for more than 8 weeks in adults [28], and sputum or saliva mixed with mucus from the respiratory tract and ejected from the mouth were observed. Fl or the treatment of CB local anesthetics either orally or inhaled form should be prescribed; ceftazidime is effective and well tolerated in patients with severe chronic bronchitis and purulent sputum [29-31].

\subsection{Allergic rhinitis $(R A)$}

Allergic rhinitis (AR) is an IgE-mediated symptomatic inflammation of upper airways with a prevalence of $10-20 \%$ in worldwide population [32]. Allergic rhinitis can increase the risk of bronchial asthma, chronic sinusitis, and otitis media [33]. Symptoms characterized by nasal congestion, sneezing, itching and rhinorrhea, and ocular effects such as eye itching, tearing and redness [34]. Treatment of AR should consider a prophylactic approach to prevent or reduce exacerbations during an acute increase in allergen [35].

\subsection{COPD}

Chronic obstructive pulmonary disease (COPD) is characterized by respiratory airways obstruction including obstruction of the small airways (chronic obstructive bronchiolitis) and emphysema leading to air trapping and shortness of breath in response to physical exertion [36]. Common features of COPD can be characterized by submucosal gland enlargement, mucous secretory cell hyperplasia in the large airways and metaplasia in the small airways and sputum production [37]. In COPD an airflow limitation is associated with abnormal inflammatory response of the lung to toxic particles or gases causing inflammation and destruction of alveolar septa leading to emphysema [38]. Use of bronchodilators including $\beta_{2-}$ agonist salbutamol, anticholinergic ipratropium bromide, $\beta_{2-}$ agonists salmeterol and formoterol, theophylline for COPD treatment can be combined with inhaled corticosteroids for greater efficacy and fewer side effects [39].

\subsection{Lung cancer}

Lung cancer is characterized as a primary cancer of the lung histological subtypes of adenocarcinoma, squamous cell and large cell cancers [40]. Prevalence of this most common malignant tumor histological types: 1) squamous cell carcinoma (30\% to $40 \%$ of lung cancers); 2) adenocarcinoma (25\% to $30 \%$ ); 3 ) nonsmall cell lung carcinoma (less than 10\%), and 4) small cell lung carcinoma (15\% to $20 \%$ ) [41]. Lung cancer causing primary type exposure and occupational substances were noted such as: chemicals and mixtures including soot, bis(chloromethyl)ether, chloromethyl methyl ether, coal gasification, iron and steel founding. General practice medical records have reported early signs and symptoms of lung cancer such as: haemoptysis, 
dyspnea, chest pain, cough appetite loss and/or weight loss up to two years before the diagnosis [42]. For the treatment of lung cancer radiotherapy can be applied [43].

\section{Conclusion}

Air sampling analyses of the working area revealed toxic gases and substances such as dust, soot, $\mathrm{SO}_{2}, \mathrm{~N}_{2} \mathrm{O}_{5}, \mathrm{~N}_{2} \mathrm{O}_{4}, \mathrm{NO}_{2}$, $\mathrm{N}_{2} \mathrm{O}$, CO and $\mathrm{H}_{2} \mathrm{~S}$ with concentrations varied from 0.06-15.8 $\mathrm{mg} / \mathrm{m}^{3}$. Concentrations, kinds of toxic substances and gases in air of the working environment were measured by the meteorological department in 28.06.2019, measurement certificate No.16/1-4. Respiratory disorders associated with changes in the mucous membrane in the respiratory tract of workers including chronic bronchitis (CB), allergic rhinitis (AR), chronic obstructive pulmonary disease (COPD) and lung cancer were described.

\section{Ethical issue}

Authors are aware of, and comply with, best practice in publication ethics specifically with regard to authorship (avoidance of guest authorship), dual submission, manipulation of figures, competing interests and compliance with policies on research ethics. Authors adhere to publication requirements that submitted work is original and has not been published elsewhere in any language.

\section{Competing interests}

The authors declare that there is no conflict of interest that would prejudice the impartiality of this scientific work.

\section{Authors' contribution}

All authors contributed to data collection, study design, data analysis, interpretation, and writing of this article.

\section{References}

1. Gangemi S, Gofita E, Costa C, Teodoro M, Briguglio G, Nikitovic $D$, Fenga C. Occupational and environmental exposure to pesticides and cytokine pathways in chronic diseases. International journal of molecular medicine. 2016; 38(4):1012-1020.

2. Kampa M, Castanas E. Human health effects of air pollution. Environmental Pollution. 2008; 151(2):362-367.

3. Tchounwou PB, Yedjou CG, Patlolla AK, Sutton DJ. Heavy metal toxicity and the environment. Experientia supplementum. 2012; 101:133-164.

4. Licht TR, Bahl MI. Impact of the gut microbiota on chemical risk assessment. Current Opinion in Toxicology. 2019; 15:109-113.

5. Bouchama A, Chastre J, Gaudichet A, Soler P, Gibert C. Acute Pneumonitis with Bilateral Pleural Effusion after Talc Pleurodesis. Chest. 1984; 86(5):795-797.

6. Jindal SK. Chronic obstructive pulmonary disease-current status and management. Medical Journal Armed Forces India. 2000; 56(3):225-228.

7. Levitsky A, Pernemalm M, Bernhardson B, Forshed J, Kölbeck K, Olin M, Wong J, Magun BE, Wood LJ. Lung inflammation caused by inhaled toxicants: a review. International journal of chronic obstructive pulmonary disease. 2016; 11:1391-1401.

8. Kerger BD, Fedoruk MJ. Pathology, toxicology, and latency of irritant gases known to cause bronchiolitis obliterans disease: Does diacetyl fit the pattern? Toxicology reports. 2015; 2:1463-1472.

9. Lim JW, Koh D. Chemical Agents that Cause Occupational Diseases. In: Cockerham WC, Dingwall R, Quah SW, editors. The Wiley Blackwell Encyclopedia of Health, Illness, Behavior, and Society, 1st edition. John Wiley \& Sons, Ltd.; 2014
10. Jones N. The nose and paranasal sinuses physiology and anatomy. Advanced Drug Delivery Reviews. 2001; 51(1-3):5-19.

11. Byber K, Flatz A, Norbäck D, Hitzke C, Imo D, Schwenkglenks M, Puhan MA, Dressel H, Mutsch M. Humidification of indoor air for preventing or reducing dryness symptoms or upper respiratory infections in educational settings and at the workplace. Cochrane Database of Systematic Reviews. 2016; 6:012219.

12. Munkholm M, Mortensen J. Mucociliary clearance: pathophysiological aspects. Clin Physiol Funct Imaging. 2014; 34: 171-177.

13. Fahy JV, Dickey BF. Airway mucus function and dysfunction. The New England journal of medicine. 2010; 363(23):2233-2247.

14. Abdullaeva Z. Nanomaterials in Daily Life: Compounds, Synthesis, Processing and Commercialization. Springer International Publishing; 2017. 149 p.

15. Reijnders L. The Cement Industry as a Scavenger in Industrial Ecology and the Management of Hazardous Substances. Journal of Industrial Ecology. 2007; 11: 15-25.

16. Duarte K, Justino CIL, Freitas AC, Duarte AC, Rocha-Santos TAP. Direct-reading methods for analysis of volatile organic compounds and nanoparticles in workplace air. TrAC Trends in Analytical Chemistry. 2014; 53:21-32.

17. Nuraydın A, Bilek Ö, Kenziman AK, Korkusuz MA, Atagün Aİ, Çakar NÖ, Özer N, Deniz S, Başaralı MK, Özlü A, Sandal A, Van der Laan G, Yıldız AN. The Mersin Greenhouse Workers Study. Surveillance of Work-related Skin, Respiratory, and Musculoskeletal Diseases. Annals of global health. 2018; 84(3):504-511.

18. Liu YZ, Roy-Engel AM, Baddoo MC, Flemington EK, Wang G, Wang $\mathrm{H}$. The impact of oil spill to lung health--Insights from an RNA-seq study of human airway epithelial cells. Gene. 2016; 578(1):38-51.

19. London NR, Lina I, Ramanathan MJr. Aeroallergens, air pollutants, and chronic rhinitis and rhinosinusitis. World journal of otorhinolaryngology - head and neck surgery. 2018; 4(3):209-215.

20. Sturgess JM. Mucous Secretions in the Respiratory Tract. Pediatric Clinics of North America. 1979; 26(3):481-501.

21. Bascom R. The upper respiratory tract: mucous membrane irritation. Environmental Health Perspectives. 1991; 95:39-44.

22. Brandtzaeg P, Kiyono H, Pabst R, Russel MW. Terminology: nomenclature of mucosa-associated lymphoid tissue. Mucosal Immunol. 2008; 1:31-37.

23. Salyer SW. Chapter 15. Pulmonary Emergencies. In: Essential Emergency Medicine. Saunders; 2007. p. 844-913.

24. Kim V, Criner GJ. Chronic bronchitis and chronic obstructive pulmonary disease. American journal of respiratory and critical care medicine. 2013; 187(3):228-237.

25. Dotan Y, So JY, Kim V. Chronic Bronchitis: Where Are We Now? Chronic obstructive pulmonary disease. 2019; 6(2):178-192.

26. Ferré $\mathrm{A}$, Fuhrman $\mathrm{C}$, Zureik $\mathrm{M}$, Chouaid $\mathrm{C}$, Vergnenègre $\mathrm{A}$, Huchon G, Delmas M-C, Roche N. Chronic bronchitis in the general population: Influence of age, gender and socio-economic conditions. Respiratory Medicine. 2012; 106(3):467-471.

27. Al-Ansari E. Chapter: Dyspnea. In: Mushlin SB, Greene II HL, editors. Decision Making in Medicine. $3^{\text {rd }}$ edition. Mosby; 2010.768 p.

28. Madison JM, Irwin RS. 63-Approach to the Patient with Chronic Cough. In: Adkinson NF, Bochner BS, Burks AW, Busse WW, Holgate ST, Lemanske RF, et al. Middleton's Allergy. $8^{\text {th }}$ edition. Saunders; 2014. p. 1032-1041.

29. Micklefield GH, Schött D, Zimmermann I, Ulmer WT. Treatment of severe chronic bronchitis with ceftazidime. Journal of Hospital Infection. 1990; 15(SupplA):65-67.

30. Kaplan AG. Chronic Cough in Adults: Make the Diagnosis and Make a Difference. Pulm Ther. 2019; 5:11-21.

31. Mifflin Harcourt.

https://www.collinsdictionary.com/dictionary/english/sputum 
32. Toppila-Salmi S, van Drunen CM, Fokkens WJ, Golebski K, Mattila P, Joenvaara S, Renkonen J, Renkonen R. Molecular mechanisms of nasal epithelium in rhinitis and rhinosinusitis. Curr Allergy Asthma Rep. 2015; 15(2):495.

33. Kozlov V, Lavrenova G, Savlevich E. Evidence-based phytotherapy in allergic rhinitis. Clin Phytosci. 2018; 4(23):1-8.

34. Canonica GW, Compalati E. Minimal persistent inflammation in allergic rhinitis: implications for current treatment strategies. Clinical and experimental immunology. 2009; 158(3):260-271.

35. Storms WW. Minimal persistent inflammation, an emerging concept in the nature and treatment of allergic rhinitis; the possible role of leukotrienes. Annals of Allergy, Asthma \& Immunology. 2003; 91(2):131-140.

36. Bracke KR, Brusselle GG. Chapter: Chronic Obstructive Pulmonary Disease. In: Mestecky J, Strober W, Russell M, Cheroutre H, Lambrecht BN, Kelsall B, editors. Mucosal Immunology. $4^{\text {th }}$ edition. Elsevier; 2015. 2540 p.

37. Barnes P, Burney P, Silverman E, Bartolome RC, Jørgen V, Jadwiga AW, Emiel FMW. Chronic obstructive pulmonary disease. Nat Rev Dis Primers. 2015; 1:15076.

38. Hanania NA, Ambrosino N, Calverley P, Cazzola M, Donner CF, Make B. Treatments for COPD. Respiratory Medicine. 2005; 99(Suppl2):S28-S40.

39. Bradley SH, Kennedy MPT, Neal RD. Recognising Lung Cancer in Primary Care. Adv Ther. 2019; 36:19-30.

40. Hammerschmidt $\mathrm{S}$, Wirtz $\mathrm{H}$. Lung cancer: current diagnosis and treatment. Deutsches Arzteblatt international. 2009; 106(49):809820.

41. Field RW, Withers BL. Occupational and Environmental Causes of Lung Cancer. Clinics in Chest Medicine. 2012; 33(4):681-703.

42. Jones GS, Baldwin DR. Recent advances in the management of lung cancer. Clinical medicine (London, England). 2018; 18(Supp12):s41-s46.

43. Jett JR, Schild SE, Kesler KA, Kalemkerian GP. Treatment of small cell lung cancer: Diagnosis and management of lung cancer, $3^{\text {rd }} \mathrm{Ed}$ American College of Chest Physicians evidence-based clinical practice guidelines. Chest. 2013; 143(Suppl5):e400S-e419S. 